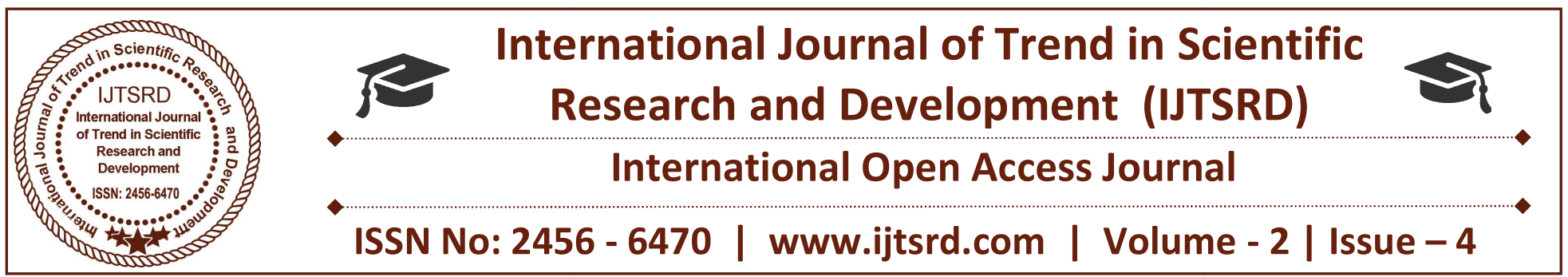

\title{
A Review on Antimicrobial Activity of Honey
}

\author{
Patel Vivek $^{1}$, Dr. Naga Rathna Supriya ${ }^{2}$ \\ ${ }^{1}$ Student, ${ }^{2}$ Assistant Professor
}

C. G. Bhakta Institute of Biotechnology, Uka Tarsadia University, Gujarat, India

\begin{abstract}
Honey is one of the natural valuable gift that has been used since ancient times to treat number of infections without any side effects. The present review has highlighted on the importance of honey and its antimicrobial properties by emphasizing the major compound that contribute to the inhibition of bacterial infection. Various mechanisms of how honey is provoking the antimicrobial activity has been describe in detail and also present scenario on honey as antimicrobial agent research reported till date has been included.
\end{abstract}

Keywords: Honey, antimicrobial, infections, medicinal field.

\section{INTRODUCTION}

Honey is one of the nature's wonders that have been used in therapy since ancient times. Honey has a long history of human consumption due to its nutritional as well as medicinal properties. Due to the lack of scientific proof honey is limited for using in modern medicine therapy (1). Several investigations have been going on since few decades to prove honey as a best source for treating many disorders, infections without or less side effects. One of the most remarkable discoveries was antibacterial activity of honey that has been mentioned in numerous studies $(2,3)$. The global production of honey is approximately 1.20 million tons per annum (4). The branch of medicine using honey bee products, including honey, pollen, propolis, royal jelly and bee venom is called Apitherapy.320 different varieties of honey have been reported till date (5). Bases on their origin of floral sources honey has different flavor, color, and odor of a specific type of honey are depending on the various liquid sources of the flowers and plants visited by the honey bee. Assorted types of honey are comparable in terms of temperature, rainfall and seasonal and climactic changes. Honey color ranges from light brown to dark brown depending on where the honey bees buzzed (6).

Figure:-1 Different pharmacological activity of honey (7)

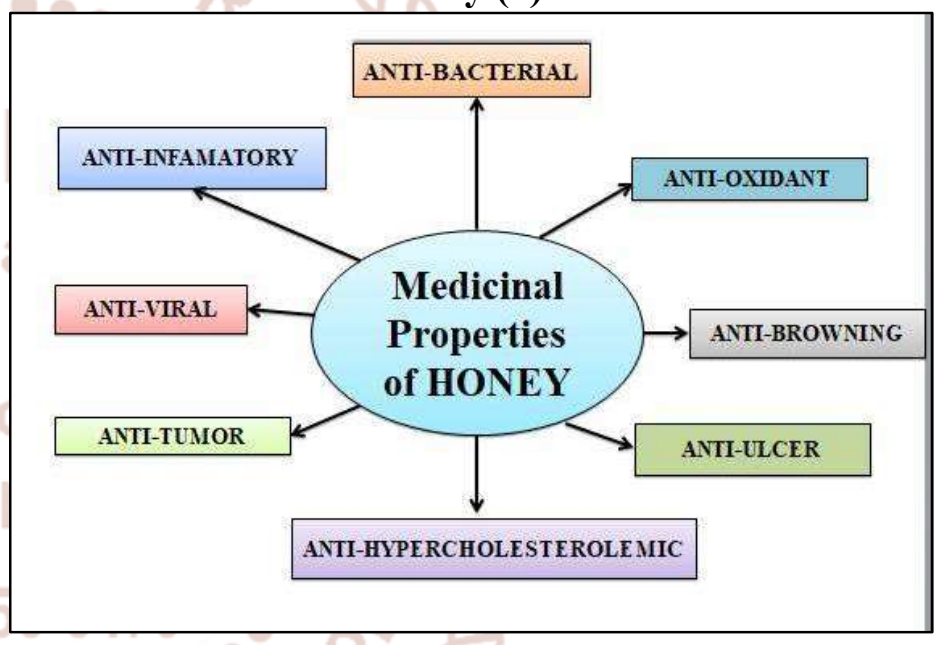

Ancient reports on importance of honey:

Consumption of honey has been traced to some 8000 years ago as depicted by Stone Age paintings (8). Nutritional and medicinal qualities of honey have been documented in many books of Vedic, Greek, Roman, Christian, Islamic. Many physicians of ancient times have been using honey for so many healing properties like Aristotle (384-322 BC), Aristoxenus (320 BC) Hippocrates, Porphyry, Cornelius Celsus (early first century AD) and Dioscorides (c. 50 AD), and Arab .In the earliest Hindu Vedic texts, honey is one of the five ingredients of Panchamrit (9). In Ayurveda medicine honey was used in India for at least 4000 years and is considered to affect positively in all three primitive material imbalances of the body. Ancient Egyptian physicians used honey in medicinal compounds 5,000 
years ago and the ancient Greeks believed that honey could promote virility and longevity. Honey has been used in Traditional Chinese Medicine for thousands of years and is still important today. Ancient Russian manuscripts attributed great importance to honey as a medicine. In $1000 \mathrm{BC}$, honey was a Saxon herbal treatment for wounds, sties and amputated limbs. The use of honey as a therapeutic cure in various combinations was popularized in Medieval Europe, England, Germany, Finland, Ireland, Ghana, USA, Nepal, Nigeria, Russia, and Brazil (10). In Christendom, there are references made to the importance of bees and honey in the Bible, these include the Books of Exodus, Judges, Mathew and Proverbs. In accordance with this Christian holy book, the Bible, King Solomon was quoted thus: "Eat honey my son, because it is good". The religion of Islam recommended the use of honey as food and medicine, and even named an entire chapter in the Holy Qur'an called Surah al Nahl meaning chapter of the Honeybee. In the book of hadith, Prophet Muhammad strongly advocated the use of honey for curative and healing purposes. Likewise, the Holy Prophet of Muslims, Mohammad (PBUH) commended the usage of honey for remedying diarrhea. Prophet Mohammad himself spoke of the healing power of honey as a cure for all mental illness. In the later part of the 12th century, a Muslim physician described the healing powers of honey to disperse body fluids, soothing the bowels, curing dropsy, checking facial twitches, improving appetite, preventing the breakdown of muscles and preserving them (11).

Egyptian use honey to treat around 900 medicinal cases (12).Its prescription revealed in the Smith papyrus (an Egyptian text, dating between 2600 and 2200 B.C.) calls for a mixture of byt (honey), mrht (grease), and ftt (lint/fibre) as a typical wound lotion. Early Egyptians offered honey as a sacrifice to their goddesses. Infected injuries were healed by honey because of its antiseptic assets. Moreover, honey was operated as a contemporary ointment. People of Egypt use honey to make sweeter bakery products and other dishes in ancient times. Middle-Eastern and Egypt people also used honey for mummifying the dead. An experimental trial in Egypt indicated that continuous ingestion of honey could affect type 1diabetes. Honey oral rehydration solution promoted in Egypt for recovery from diarrhea, vomiting and rehydration (13). There is a prehistoric Greek Honey utilized occasionally as a conventional remedy for gout and few nervous disorders. A simple diet (honey) proposed by Greek scientist, preferred as hydromel (honey and water) for quenching thirst, oxymel (honey and vinegar) for pain and a combination of medicinal constituents (13). Honey had also been utilized for sore throat, laxative action, contraception, eye diseases, baldness, wound healing, cure and inhibition of scratches by him (8).

\section{Bioactive Compounds of Honey:}

200 bioactive compounds are reported till date disaccharides, monosaccharides, oligosaccharides, amino acids, vitamins, minerals, enzymes, Flavonoids, phenolic acids, Millard reaction products and peptides $(4,14-18)$.

\section{Figure: 2Bioactive Compounds of Honey}

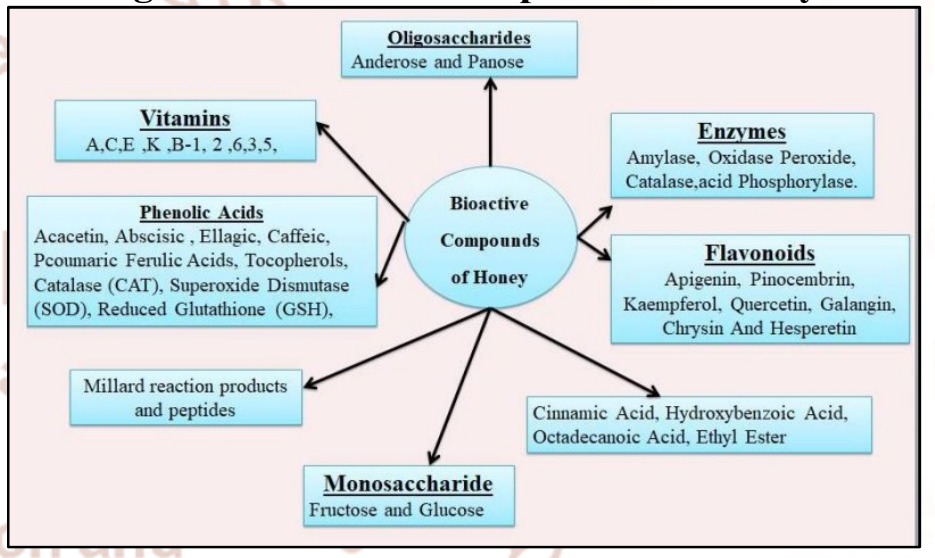

\section{Antibacterial activity of honey:}

VanKetel has first time reported the antimicrobial activity of honey in 1892 (19).Multi drug resistant bacterial strains are emerging day by day due to many factors which include personal and environment factors. Although many antimicrobial agents are in use for therapy, honey has an important place in treating of microbial infections. Honey the nature gift because of no side effects compared to the drugs available now a days.Mohapatraetal.,2011, Irish et al.,2011, Alnaimat et al.,2012 reported antimicrobial activity of honey may be bacteriostatic or bactericidal depending on components present in the honey (2022). There are less chances of bacterial exhibiting resistance to honey due to their variability in composition like 1) types of nectar that the bees fed, (2) the related weather conditions, (3) storage time and (4) conditions of preservation $(23,24)$. Bilselet al., 2002 stated that $\mathrm{pH}$ of honey contributes to prevent the growth of many Bacteria; example acidic $\mathrm{pH}$ containing honey has been reported to be a potential antimicrobial agent (25).In 2009, a study sated that honey shows antibacterial activity by inhibiting the biofilm formation by Methylglyoxal 
which is an important property for the bacteria like $S$. aureus and $P$. aeruginosa to cause infection by adhering to the wound $(26,27)$. Halawani and Shohayeb (2011) has also stated that there was no relationship between color and antibacterial activity of honey because some honeys of light coloration like orange blossom and clover, were potential antibacterial against Salmonella enteritidis than dark honeys (28).

\section{Mechanism of antimicrobial activity of honey:}

Previous reports of experiments have stated that antimicrobial property of honey may be due to reducing sugars, high viscosity, high osmotic pressure, low water activity, low protein and $\mathrm{pH}$, phenolic content, Methylglyoxal and hydrogen peroxide (29-33).Few mechanisms like degrade DNA, radical scavenging activity, inhibition of biofilm formation by reducing the expression of 2 fibronectinbinding proteins by Methylglyoxal, Quorum sensing inhibitory activity of hydrogen peroxide or by down regulated 2 specific proteins that are necessary for growth and up regulated a stress-related protein (coldshock protein $\mathrm{C}$ ) were reported in previous literature (33-44).Cooper et al., 2011b stated that biofilms formation can prevented by down regulating of two genes coding for surface-binding proteins which were found to contribute to the prevention of biofilm formation (45).honey inhibits cell division and involves in multiple changes of cellular proteins that effect infection (46)whereas gene expression (47)and causing changes in the bacterial cell wall that led to instabilities, resulting in cell lysis $(46,48,49)$.

Some of the compounds that contribute to the antimicrobial activity of honey are presented in Figure:-2 (33-43, 50, 51)

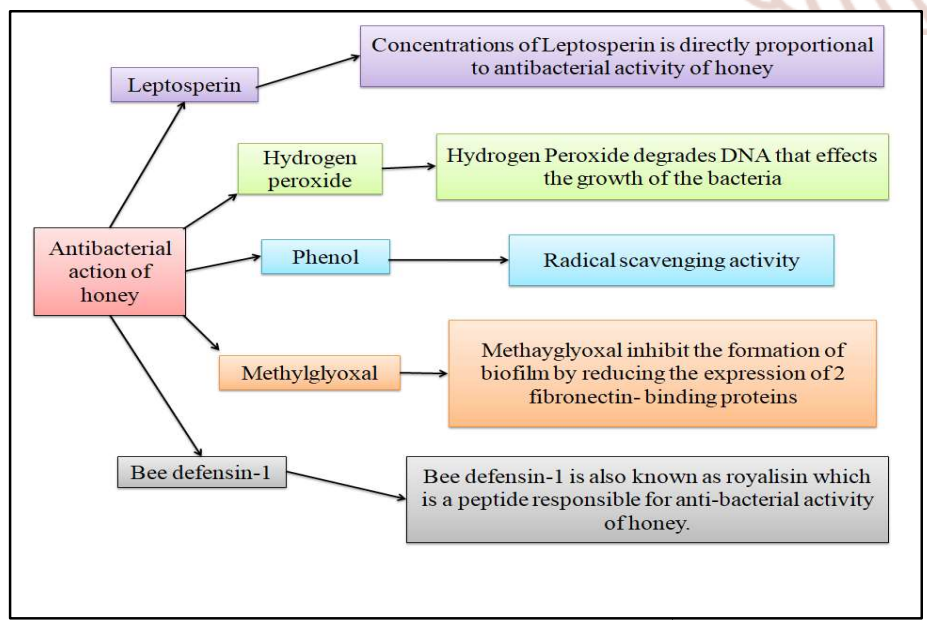

Sensitive bacteria towards honey:

Honey has been reported to have an inhibitory effect to around 60 species of bacteria including aerobes and anaerobes, gram-positives and gram-negatives (52). Ram meena , rajgopalacharya reported manuka honey and pasture honey shows antibacterial effect on E.coli, P.aeruginosa, S.aureus, V.chlorelae, Serratiamarceseens, proteus spp. (53). Several reports have proved the broad spectrum activity of honey on diverse species of bacteria such as Acinetobacterbaumannii, Alcaligenes faecalis, Aeromonashydrophila, Bacillus cereus , B. subtilis ,Burkholderiacepacia, Campylobacter spp., Citrobacter freundii, Erwiniacarotovora, Enterobacter aerogenes, Enterobacter cloacae, vancomycin-resistant Enterococcus faecium, Escherichia coli, Haemophilus influenza, Helicobacter pylori, Klebsiella oxytoca, $K$. pneumonia, Listeria monocytogenes, Micrococcus luteus, Mycobacterium phlei, Proteus sp (P. mirabilis and $P$. vulgaris), Pseudomonas aeruginosa, Salmonella (S. A california, S.enteritidis, S.typhimurium), Serratiamarcescens, Shigella dysenteriae, Shigella sonnei, Staphylococcus aureus,MRSA, $S . \quad$ epidermidis, Stenotrophomonasmaltophilia, Streptococcus hemolyticus group B, Streptococcus pyogenes, Yersiniaenterocolitica and several multidrug-resistant bacterial isolates (54-85).

\section{National and international Reports on Antimicrobial activity of honey:}

Research on evaluating honey's antimicrobial property has been in progress and available reports are mention in this review.

Allen et al.,1991 reported variation in antibacterial activity of 345 unpasteurized honey samples collected from New Zealand which are mostly unifloral of 26 different floral sources like Kanuka (Kunzeaericoides), manuka (Leptospermum scoparium), ling heather (Calluna vulgaris) and kamahi (Weinmanniaracemosa) (69). Willixet al., 1992 compared the non-peroxide activity of manuka honey with that of a peroxide-producing honey against several pathogenic wound bacteria and reported that there was no significant difference between the two types of activity overall but there was marked differences existed in the ranking order of sensitivity because $1.8 \%(\mathrm{v} / \mathrm{v})$ of manuka honey was enough to completely inhibit the growth of $S$. aureus after $8 \mathrm{~h}$ of incubation whereas the other one was $11 \%$ 
(v/v) (86). Lusby et al., 2005 reported that low concentration of Tualang honey was showing antimicrobial activity against gastric infection causing bacteria S. typhi, S. flexneri and E. coli (62). Hegazi and Fyrouz, 2011 reported 40 to $80 \%$ concentration of honey sample collected from Sidr and Mountain region of Saudi were inhibiting E. coli.(87) Roslanet al.,2015 has reported $40 \%$ honey dilution showed higher inhibitory effect on E. coli (88) Stratevest al.2015 reported various concentrations of royal jelly $[10,20$, and 30\%] possess inhibitory effect against $A$. hydrophila ATCC 7965 (89). Taormina et al.,2001 reported against 5 pathogens $E$.coli, S. typhimurium, Shigella sonnei, Listeria monocytogenes , S. aureus .(71)Manyi-Loh CE reported against Helicobacter pylori (90). Minimum inhibitory concentration of Commercial Agmark honey purchased from Khadikraft, India was reported as $11 \%$ against Pseudomonas aeruginosa isolated from diabetic foot ulcers and burn wound infections (91). Wilkinson and Cavanagh (2005) reported that MIC of different honey samples were showing variation and in general $50 \%$ and $20 \%$ of honey showed antimicrobial effect on P. aeruginosa (76). Hegazi (2011) reported antimicrobial activity of honey from various sources like Acacia honey, Citrus honey, Clover honey, Coriander honey, Cotton honey, Palm honey, Sesame honey and Saudi Seder honey against Klebsiella, pneumonia, $P$. aeruginosa and Escherichia coli have their significant property of inhibiting the bacterial pathogens (92). Mohapatra et al., 2011; Irish et al.,2011; Alnaimat et al., 2012 reported the antimicrobial activity of honey against 5 Gram positive bacteria (Staphylococcus aureus, Bacillus subtilis, Bacillus cereus, Enterococcus faecalis, and Micrococcus luteus) and 3 Gram negative bacteria (E. coli, P. aeruginosa, and Salmonella typhi) (20-22). Mamatha Ballalet al 2012 has reported that all strains of $P$. aeruginosa including both resistant phenotypes and sensitive strains were inhibited at $20 \%$ antibacterial honey concentrations in vitro (93). Abd-El Aalet al. 2007 showed that honey had a more pronounced inhibitory effect $(85.7 \%)$ on Gram negative bacteria (Pseudomonas aeruginosa, Enterobacter spp., Klebsiella) in comparison to commonly used antimicrobial agents. 100\% inhibition was observed in the case of Gram positive methicillinresistant Staphylococcus aureus in comparison to the use of antibiotics alone (94). Cooper et al., 2002 reported that concentration less than 10\%, Manuka Honey was inhibiting the 58 strains of Gram-positive
MSSA and 18 strains of MRSA isolated from wounds $(95,96)$.

Elin Juliantiet al., 2017 reported MICs of honey against Propionibacterium acnes and Staphylococcus epidermidis and stated that combination of extract of cinnamon bark and honey against showed an additive activity with a FracICI value of 0.625 suggesting that the extract of cinnamon bark and honey have good potential activity against acne-causing bacteria (97). The lowest concentration of sugar that prevents the growth of $\mathrm{S}$. aureus has a water activity of 0.86 , equivalent to a concentration of $29 \%(\mathrm{v} / \mathrm{v})$. This is equivalent to a concentration of honey of $22 \%$. In the present study, both of the honeys inhibited S. aureus completely at much greater dilution. This is because their mode of action is not exclusively through their osmolarity (98). The lack of significant variance in the sensitivity of a large number of clinical isolates collected from a wide range of wounds indicates that there is no mechanism of resistance to either of the additional types of antibacterial activity in honey (phytochemical or hydrogen peroxide). This contrasts with the variations seen in staphylococcal sensitivity to antibiotics (99). Thus, either of these two honeys might be an effective treatment for a wound infected with any strain of S. aureus. However, although their MIC values differed little in vitro, in vivo the hydrogen peroxide produced in mixed pasture honey would be partly inactivated by the catalase in tissues and blood and manuka honey with its non-peroxide antibacterial activity is likely to be more effective. Their relative merits need to be tested in clinical trials (82).

\section{References:}

1. Ali AT, Chowdhury MN, Al Humayyd MS. Inhibitory effect of natural honey on Helicobacter pylori. Trop Gastroenterol 1991; 12:139-143.

2. Al-Waili NS, Haq A. Effect of honey on antibody production against thymus-dependent and thymus independent antigens in primary and secondary immune responses. J Med Food 2004; 7: 491-494.

3. Emsen IM. A different and safe method of split thickness skin graft fixation: Medical honey application. Burns 2007; 33:782-787.

4. Bogdanov, S., Jurendic, T., Sieber, R., Gallmann, P., Honey for nutrition and health: a review. J. Am. Coll. Nutr. 2008;27 (6), 677-689.

5. Ezz El-Arab, A .M. , S. M. Girgis, M. E. Hegazy and Abd A. B. El-Khalek,. Effect of dietary honey 
International Journal of Trend in Scientific Research and Development (IJTSRD) ISSN: 2456-6470

on intestinal micro flora and toxicity of mycotoxins in mice.BMC Complement Altern., 2006; 6: 1-13.

6. http://www.honeyo.com/types.shtml

7. Manjunathadevagondanahallihagadi, lee sui, the anti-inflammatory activity and wound healing property of honey. European food research and technology 2009,pp 1003-1014.

8. Bansal V, Medhi B, Pandhi P. Honey -A remedy rediscovered and its therapeutic utility. Kathmandu Univ Med J 2005; 3:305-309.

9. Ali, A. T. M. Chowdhury, M. N. H. Humayyd, M. S. A., Inhibitory effect of natural honey on Helicobacter pylori., Tropical Gastroenterology, 1991;12 (3): 139-143.

10. Altman, Nathaniel. The Honey Prescription: The Amazing Power of Honey as Medicine., 2010; ISBN 978- 1-59477-346-4.

11. Molan PC, Why honey is effective as a medicine. 1. Its use in modern medicine. Bee World 1999; $80: 80-92$

12. Al-Jabri AA. Honey, milk and antibiotics. Afr J Biotechnol 2005; 4:1580-1587.

13. Zumla A, Lulat A. Honey $-\mathrm{a}$ remedy rediscovered. J Royal Soc Med 1989; 82:384-385.

14. Muhammad, A., Odunola, O. A., Gbadegesin, M. A., Sallau, A. B., Ndidi, U. S., Ibrahim, M. A., 2015. Inhibitory effects of sodium arsenite and acacia honey on acetyl cholinesterase in rats. Int. J. Alzheimer's Dis. 2015, 903603.

15. White JW. Composition of honey. In: Crane E, editor. Honey: A Comprehensive Survey. London, Heinemann 1979; pp. 157-192.

16. Alvarez-Suarez JM., Tulipani S., Romandini S., Bertoli E., Battino M. Contribution of honey in nutrition and human health: a review. Mediterranean Journal of Nutrition and Metabolism 2010; 3:15-23.

17. Kumar KPS., Bhowmik D., Chiranjib ., Biswajit and Chandira MR. Medicinal uses and health benefits of Honey : An Overview . Journal of Chemical and Pharmaceutical Research 2010; 2(1): 385-395.

18. Al-Mamary M., Al-Meeri A., Al-Habori M. Antioxidant activities and total phenolics of different types of honey. Nutrition Research 22 (2002); 1041.
19. Dustmann JH. Antibacterial effect of honey. Apiacta. 1989;14(1):7-11.

20. D. P. Mohapatra, V. Thakur, S. K. Brar Antibacterial efficacy of raw and processed honey Biotechnol. Res. Int. 2011, p.6Article ID 917505.

21. J. Irish, S. Blair, D.A. Carter The antibacterial activity of honey derived from Australian flora PLoS One, 6 (2011), p. e18229.

22. S. Alnaimat, M. Wainwright, K. Al'AbriAntibacte rial potential of honey from different origins: a comparison with Manuka Honey J. Microbiol. Biotechnol. Food Sci., 1 (2012), pp. 1328-1338.

23. O. Sherlock, A. Dolan, R. Athman, A. Power, G. Gethin, S. Cowman, H. HumphreysComparison of the antimicrobial activity of Ulmo honey from Chile and Manuka honey against methicillinresistant Staphylococcus coli and Pseudomonas aureus, Escherichia Complement Altern. Med $10(10)(2010)$ p. $47,10.1186 / 1472-6882-10-47$

24. N. S. Al-Waili, N. S. BoniNatural honey lowers plasma prostaglandin concentrations in normal individuals J. Med. Food, 6 (2003), pp. 129-133

25. Bilsel, y; Bugra, d; Yamaner, s; Bulut, t; Cevikbas, u; Turkoglu, u Could honey have a place in colitis therapy? Effects of honey, prednisolone, and disulfiram on inflammation, nitric oxide, and free radical formation. Digestive Surgery, 2002, 19 (4): 306-311.

26. Patricia merckoll, Tom Øystenjonassen, Marie Elisabeth vad, Stig 1. jeansson\&Kjetil k. melby Scandinavian Journal of Infectious Diseases, 2009; 41: 341_347

27. Talal Alandejani, MD, Joseph Marsan, MD, FRCSC, Wendy Ferris, BSc, MLT, MSc, Robert Slinger, MD, FRCPC, and Frank Chan, MSc, $\mathrm{PhD}$, Ottawa, ON, Canada Otolaryngology-Head and Neck Surgery (2009) 141, 114-118.

28. N.G. Vallianou, P. Gounari, A. Skourtis, J. Panag os, C. KazazisHoney and its anti-inflammatory, anti-bacterial and anti-oxidant properties General Med., 10 (2014),p. 132, 10.4172/2327-

5146.1000132

29. Kwakman, P. Zaat, S. Antibacterial components of honey. In IUBMB Life, vol. 64, no. 1, 2012.p. 48-55. 
International Journal of Trend in Scientific Research and Development (IJTSRD) ISSN: 2456-6470

30. Kačániová, M. Vukovic, N. Bobková, A. Fikselová, M. Rovná, K. Haščík, P. Čuboň, J. Hleba, L. Bobko, M. 2011. Antimicrobial and antiradical activity of Slovakian Honeydew honey samples. In The Journal of Microbiology, Biotechnology and Food Sciences, vol. 1, 2011, no. 3, p. 354-36.

31. Saleh I., Barbour E., Kumosani T., Harakeh S. Nova Science Publishers, Inc.; Hauppauge, NY11788: Cheese as a Reservoir for Antimicrobial Resistance of Escherichia coli and Staphylococcus spp. Advances in Medicine and Biology. 2011.

32. Jing P., Xu W., Yi H., Wu Y., Bai L., Yuan R. An amplified electrochemical apt sensor for thrombin detection based on pseudobienzymic $\mathrm{Fe}_{3} \mathrm{O}_{4}-\mathrm{Au}$ nanocomposites and electroactivehemin/Gquadruplex as signal enhancers. Analyst. 2014; 139:1756-1761.

33. Brudzynski K, Abubaker K, Miotto D. Unraveling a mechanism of honey antibacterial action: polyphenol/ $\mathrm{H} 2 \mathrm{O} 2$-induced oxidative effect on bacterial cell growth and on DNA degradation. Food Chem. 2012;133;329-336.

34. Mavric E, Wittmann S, Barth G, et al. Identification and quantification of methylglyoxal as the dominant antibacterial constituent of Manuka (Leptospermum scoparium) honeys from New Zealand. Mol Nutr Food Res. 2008;52:483489.

35. Molan PC. The antibacterial activity of honey. 2 -Variation in the potency of the antibacterial activity. Bee World. 1992;73:59-76.

36. Jenkins R, Burton N, Cooper R. Manuka honey inhibits cell division in methicillin-resistant Staphylococcus aureus. J Antimicrob Chemother. 2011; 66:2536-2542.

37. Kwakman PH, TeVelde AA, de Boer L, et al. Two major medicinal honeys have different mechanisms of bactericidal activity. PLoS One. 2011;6:e17709.

38. Jenkins RE, Cooper R. Synergy between oxacillin and manuka honey sensitizes methicillin-resistant Staphylococcus aureus to oxacillin. J Antimicrob Chemother. 2012; 67:1405-1407.

39. Alnaqdy A, Al-Jabri A, Al Mahrooqi Z, et al. Inhibition effect of honey on the adherence of
Salmonella to intestinal epithelial cells in vitro. Int J Food Microbiol. 2005; 103:347-351.

40. Maddocks SE, Lopez MS, Rowlands RS, et al. Manuka honey inhibits the development of Streptococcus pyogenes biofilms and causes reduced expression of two fibronectin binding proteins. Microbiology. 2012; 158:781-790.

41. Truchado P, López-Gálvez F, Gil MI, et al. Quorum sensing inhibitory and antimicrobial activities of honeys and the relationship with individual phenolics. Food Chem. 2009; 115:1337-1344.

42. Truchado P, Gil-Izquierdo A, Tomás-Barberán F, et al. Inhibition by chestnut honey of N-Acyl-Lhomoserine lactones and biofilm formation in Erwiniacarotovora, Yersinia enterocolitica, and Aeromonashydrophila. J Agric Food Chem. 2009; 57:11186-11193.

43. Packer JM, Irish J, Herbert BR, et al. Specific non-peroxide antibacterial effect of manuka honey on the Staphylococcus aureus proteome. Int $\mathbf{J}$ Antimicrob Agents. 2012; 40:43-50.

44. Halawani E, Shohayeb M. Survey of the antibacterial activity of Saudi and some international honeys. J. Microbiol. Antimicrob. 2011, 3:94- 101 .

45. Cooper, R. A., Lindsay, E. \&Molan, P. C. Testing the susceptibility to manuka honey of streptococci isolated from wound swabs. J Apiprod ApimedSci 3, 2011, 117-122.

46. Henriques, A. F., Jenkins, R. E., Burton, N. F. \& Cooper, R. A. The effect of manuka honey on the structure of Pseudomonas aeruginosa. Eur J Clin Microbiol Infect Dis 30, 2011, 167-171.

47. Blair, S. E., Cokcetin, N. N., Harry, E. J. \& Carter, D. A. The unusual antibacterial activity of medical-grade Leptospermum honey: antibacterial spectrum, resistance and transcriptome analysis. Eur J Clin Microbiol Infect Dis 28, 2009,11991208.

48. Aled E. L. Roberts, Sarah E. Maddocks and Rose A. Cooper Microbiology (2012), 158, 3005-3013.

49. Brudzynski K, Abubaker K, Martin L, Castle A: Re-examining the role of hydrogen peroxide in bacteriostatic and bactericidal activities of honey. Front microbiol. 2011, 2: 213. 
50. Kato Y, Umeda N, Maeda A, Matsumoto D, Kitamoto N, Kikuzaki H. Identification of a novel glycoside, leptosin, as a chemical marker of manuka honey. $J$ Agric Food Chem. 2012;60(13):3418-3423.

51. Kato Y, Fujinaka R, Ishisaka A, Nitta Y, Kitamoto $\mathrm{N}$, Takimoto Y. Plausible authentication of manuka honey and related products by measuring leptosperin with methyl syringate. J Agric Food Chem. 2014;62(27):6400-6407.

52. Hannan A, Barkaat M, Saleem S, Usman M, Gilani WA. Manuka honey and its antimicrobial potential against multi drug resistant strains of Typhoidal salmonellae. Lahore, Pakistan: Department of Microbiology, University of Health Science; 2004. Ph.D. thesis.

53. Ram meena; rajgopalacharya, International Journal of Applied and Natural Sciences (IJANS) 2016 ;Vol. 5; 9-14 .

54. MolanPC . The antibacterial activity of honey: 2. Variation in the potency of the antibacterial activity. Bee World. 1992,73:59-76.

55. Chang X, Wang J, Yang S, et al. Antioxidative, antibrowning and antibacterial activities of sixteen floral honeys. Food Funct. 2011; 2:541-546.

56. Al-Waili NS, Akmal M, Al-Waili FS, et al. The antimicrobial potential of honey from United Arab Emirates on some microbial isolates. Med SciMonit. 2005; 11:433- 438.

57. Alvarez-Suarez JM, Tulipani S, Diaz D, et al. Antioxidant and antimicrobial capacity of several monofloral Cuban honeys and their correlation with color, polyphenol content and other chemical compounds. Food ChemToxicol. 2010; 48:2490 2499.

58. Al-Hindi RR, Bin-Masalam MS, El-Shahawi MS. Antioxidant and antibacterial characteristics of phenolic extracts of locally produced honey in Saudi Arabia. Int J Food Sci Nutr. 2011; 62:513517.

59. Voidarou C, Alexopoulos A, Plessas S, et al. Antibacterial activity of different honeys against pathogenic bacteria. Anaerobe. 2011; 17:375-379.

60. Efem SEE, Udoh KT, Iwara CI. The antimicrobial spectrum of honey: its clinical significance. Infection. 1992; 20: 227-229.
61. Lusby PE, Coombes A, Wilkinson JM. Honey: a potent agent for wound healing? J Wound Care. 2002; 29:295-300.

62. Lusby PE, Coombes AL, Wilkinson JM. Bactericidal activity of different honeys against pathogenic bacteria. Arch Med Res. 2005; 36:464-467.

63. Tan HT, Rahman RA, Gan SH, et al. The antibacterial properties of Malaysian tualang honey against wound and enteric microorganisms in comparison to manuka honey. BMC Complement Altern Med. 2009; 9:34.

64. Kwakman PH, Te Velde AA, de Boer L, et al. Two major medicinal honeys have different mechanisms of bactericidal activity. PLoS One. 2011; 6:e17709.

65. Farid H. Application of natural honey for treatment of multidrug-resistant Pseudomonas aeruginosa in the burn unit alshifa hospital, Gaza, Palestine. Clin Chem Lab Med. 2012; 50:A116.

66. Kwakman PHS, TeVelde AA, de Boer L, et al. How honey kills bacteria. FASEB J. 2010; 24:2576-2582.

67. Brady N, Molan P, Bang L. A survey of nonmanuka New Zealand honeys for antibacterial and antifungal activities. J Apicul Res. 2004; 43:4752.

68. Ali ATMM, Chowdhury MNH, Al-Humayyd MS. Inhibitory effect of natural honey on Helicobacter pylori. Trop Gastroenterol. 1991; 12:139-143.

69. Allen K, Molan P, Reid G. A survey of the antibacterial activity of some New Zealand honeys. J Pharm Pharmacol. 1991; 43:817-822.

70. Al Somal N, Coley KE, Molan PC, et al. Susceptibility of Helicobacter pylori to the antibacterial activity of Manuka honey. J R Soc Med. 1994;87:9-12.

71. Taormina P, Niemira B, Beuchat L. Inhibitory activity of honey against foodborne pathogens as influenced by the presence of hydrogen peroxide and level of antioxidant power. Int $\mathrm{J}$ Food Microbiol. 2001; 28:217-225.

72. Al-Jabri AA, Al-Hosni SA, Nzeako BC, et al. In vitro antibacterial activity of Omani and African honey. Br J Biomed Sci. 2003; 60:1-4.

73. Al-Jabri AA, Al-Hosni SA, Al-Mahrooqi ZH, et al. Antibacterial activity of Omani honey alone 
and in combination with gentamicin. Saudi Med J. $2005 ; 26: 767-771$.

74. Al-Waili NS. Mixture of honey, beeswax and olive oil inhibits growth of Staphylococcus aureus and Candida albicans. Arch Med Res. 2005; 36:10-13.

75. French VM, Cooper RA, Molan PC. The antibacterial activity of honey against coagulasenegative staphylococci. J Antimicrob Chemother. $2005 ; 56: 228-231$.

76. Wilkinson J, Cavanagh H. Antibacterial activity of 13 honeys against Escherichia coli and Pseudomonas aeruginosa. J Med Food. 2005; $8: 100-103$.

77. Mullai V, Menon T. Bactericidal activity of different types of honey against clinical and environmental isolates of Pseudomonas aeruginosa. J Altern Complement Med. 2007; $13: 439-441$.

78. Irish J, Carter DA, Blair SE, et al. Antibacterial activity of honey from the Australian stingless bee Trigonacarbonaria. Int $\mathrm{J}$ Antimicrob Agents. 2008; 32:89-90.

79. Kwakman PHS, Van Den Akker JPC, Güçlü A, et al. Medical-grade honey kills antibiotic-resistant bacteria in vitro and eradicates skin colonization. Clin Infect Dis. 2008; 46:1677-1682.

80. Lee H, Churey JJ, Worobo RW. Antimicrobial activity of bacterial isolates from different floral sources of honey. Int J Food Microbiol. 2008; 126:240-244.

81. Boukraâ L, Sulaiman SA. Rediscovering the antibiotics of the hive. Recent Pat Antiinfect Drug Discov. 2009; 4: 206-213.

82. Lin SM, Molan PC, Cursons RT. The in vitro susceptibility of Campylobacter spp. to the antibacterial effect of manuka honey. Eur J Clin Microbiol Infect Dis. 2009; 28: 339-344.

83. Truchado $\mathrm{P}$, Gil-Izquierdo A, Tomás-Barberán $\mathrm{F}$, et al. Inhibition by chestnut honey of N-Acyl-Lhomoserine lactones and biofilm formation in Erwiniacarotovora, Yersinia enterocolitica, and Aeromonashydrophila. J Agric Food Chem. 2009; 57:11186-11193.

84. Fallah F, Eslam G, Taheri S, et al. The effects of honey against E.coli resistant to cotrimoxasole in urinary tract infections in Iran. Int Med $\mathrm{J}$. 2010;40(Supp1 1):72.

85. Majtán J, Majtanova L, Bohova J, et al. Honeydew honey as a potent antibacterial agent in eradication of multi-drug resistant Stenotrophomonasmaltophilia isolates from cancer patients. Phytother Res. 2011; 25: 584587.

86. Willix, D.J., P.C. Molan and C.G. Harfoot, 1992. A comparison of the sensitivity of woundinfecting species of bacteria to the antibacterial activity of manuka honey and other honey. J. Applied Bacteriol., 73: 388-394.

87. A.G. Hegazi Antimicrobial activity of different Egyptian honey as comparison of Saudi Arabia honey J. Microbiol., 6 ;2011, pp. 488-495.

88. N. A. Roslan, H. N. Mohammad Rashed, N. H. Harun, M. H. Jamaludin, Z. Abdul Kari and A. R. Alimon. Malaysian Society of Animal Production, 2015, 18(1): 99-104

89. Stratev, D., Vashin, I., Balkanska, R. \&Dinkov, D. Antibacterial activity of royal jelly and rape honey against Aeromonashydrophila (ATCC 7965). Journal of Food and Health Science, 2015, 1(2), 64-74.

90. Manyi-Loh CE, Clarke AM, Ndip RN. Detection of phytoconstituents in column fractions of $n$ hexane extract of Goldcrest honey exhibiting antiHelicobacter pylori activity. Arch Med Res 2012; 43:197-204.

91. Cooper RA, Molan PC, Harding KG, Antibacterial activity of honey against strains of staphylococcus aureus from infected wounds. J R Soc Med 1999;92:283-5.

92. A.G. Hegazi, Antimicrobial activity of different Egyptian honey as comparison of Saudi Arabia honeyv J. Microbiol., 6 (2011), pp. 488-495

93. MamathaBallal, Vishnu Prasad Shenoy, PG Shivananda, and Indira Bairy Journal of Global Infectious Diseases. 2012 Apr-Jun; 4(2): 102105.

94. Abd-El Aal A., El-Hadidy M., El-Mashad N., ElSebaie A. Antimicrobial effect of bee honey in comparison to antibiotics on organisms isolated from infected burns. Ann. Burns Fire Disasters. 2007; 20:83. 
95. Cooper R. A., Molan P. C., Harding K. G. The sensitivity to honey of Gram-positive cocci of clinical significance isolated from wounds. J. Appl. Microbiol. 2002;93(5):857-863.

96. Hussein S. Z., Mohd Yusoff K., Makpol S., MohdYusof Y.A. Gelam honey inhibits the production of proinflammatory, mediators NO, PGE 2, TNF- $\alpha$, and IL-6 in carrageenan-induced acute paw edema in rats. Evid. Based Complement. Alt. Med. 2012.
98. Miorin, P. L., N. C. Levy Junior, A. R. Custodio, W. A. Bretzand M. C. Marcucci,. Antibacterial activity of honey and propolis from Apismellifera and Tetragoniscaangustula against Staphylococcusaureus. J. Applied Microbiol., 2003 95: 913-920.

99. Allen K. L., Molan P. C., Reid G. M. (). A survey of the antibacterial activity of some New Zealand honeys. J. Pharm. Pharmacol, 1991. 43817-822 10.1111/j.2042-7158.

97. Elin Julianti, Kasturi K. Rajah and Irda Fidrianny,2017 Sci. Pharm., 85, 19; doi:10.3390/scipharm85020019.

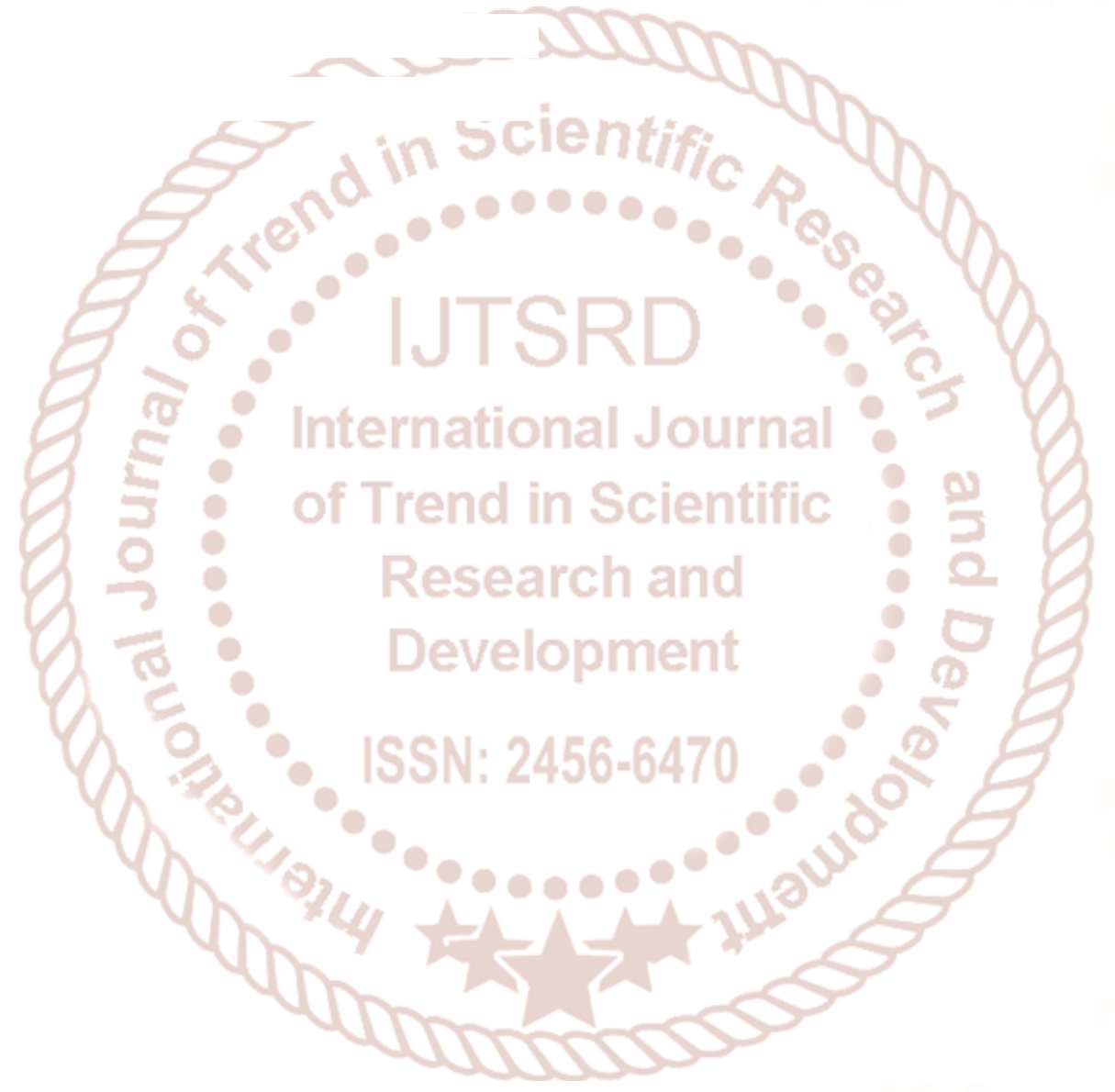

